\title{
Policy Core Belief in Policy Change
}

Aslinda

\author{
Department of Public Administration \\ State University of Makassar. \\ Makassar, South Sulawesi, Indonesia \\ aslinda110@yahoo.com
}

\author{
Muhammad Guntur
}

\author{
Department of Public Administration \\ State University of Makassar \\ Makassar, South Sulawesi, Indonesia
}

\author{
Muhammad Akmal Ibrahim \\ Department of Administrative Science \\ Hasanuddin University \\ Makassar, South Sulawesi, Indonesia
}

\begin{abstract}
Policy of spatial utilization by street vendors in Makassar city has changed from regulation determined by government. This research aims to know and analyze policy core belief from actors related to policy of spatial utilization by street vendors and impacts resulted from spatial utilization by street vendors in Makassar city. Method used in this research is qualitative with strategy of a case study. The results of this research are found that policy of spatial utilization by street vendors has changed caused by policy core belief or understanding of the government actors and street vendors in coordinating actions not based on belief equality toward achievement of policy goals. Policy impacts of spatial utilization by street vendors in Makassar city have appropriate and inappropriate parameter impact with policy.
\end{abstract}

Key words: policy core belief; policy change; spatial utilization; street vendors; Makassar City

\section{INTRODUCTION}

Public dissatisfaction with the impact of government policies on aspects of public life during the decade of implementation resulted in the implementation policy process is continuously established [1], from the passage of legislation, followed by the decision of the implementing agency on policy output, laws and regulations already revised or amended to affect changes in policy implementation. [2].

According to the latest literature says that a policy has changed, among others, (a) policy changes caused by political resources affecting policy making either in long term or short term (b), policy changes caused by internal subsystem events, (c) policy changes causeb by negotiated agreements more than two coalitions (d) Policy change caused by possible redistribution of power that resembles someone's belief system over others. (e) Policy changes caused by the core blief of the policy actors are usually result of disruption in non-cognitive of external factors to the sub system [3], The Advocacy Coalition Framework (ACF) is a theory of policy change over a long period of time. The ACF shifts the attention from a mere implementation study to a policy change study. The ACF provides an approach to the entire policy process, from adoption to policy implementation, and to understand policy changes over a long period of time [4] [5].

In South Sulawesi exactly in Makassar city, policy of spatial utilization by street vendors have changed policies that have been determined by the previous government, the change meant that is still found street vendors using sidewalks, city parks, roads to sell while based on local regulation [11] stating that street vendors are prohibited from trading/striving on streets, sidewalks and other public places, street vendors who have been permitted may not establish permanent buildings. Based on authors' observations, it was found that this policy change was partly due to the Policy core belief or the perspective of government actors and street vendors in coordinating their actions not based on the similarity of beliefs toward the achievement of the policy goals.

This research using one of variables of policy core belief [6]. This version is different from previous research that is just focused on explicit controls on lower-level implementer behavior as directed top-down theories, or on the bargaining process on lower-level implementer as directed bottom-up theories. Based on the background of this research then the formulation of this research problem is to analyze how the policy core belief of advocacy coalition in changes of spatial utilization policy by the street vendors in Makassar and how the impact of policy spatial utilization by the street vendors in Makassar.

\section{RESEARCH METHOD}

This research uses qualitative design. Focusing on spatial utilization by street vendors located in Makassar City, South Sulawesi Province. The reasons for choosing the location were the phenomenon of spatial utilization by street vendors had not reflected the security, order, as affirmed in local regulation (about street vendors) This research uses data and information from the following three sources: (1) Program records and documents/activities; (2) interviews with selected participants of street vendors and (3) direct observation [7].

\section{RESULT AND DISCUSSION}

In accordance with the problems of this research intending to analyze and discuss policy changes of spatial utilization by street vendors through policy core belief and the impact resulted from the policy of spatial utilization by street vendors.

\section{A. The form of policy changes of spatial utilization by street vendors in Makassar City}

The policy basic value of spatial utilization by the street vendors in Makassar City consists of three forms of legislation [13] about Coordination of Structuring and Empowerment of Street vendors [14], guidelines for Structuring and Empowerment of Street vendors [11]. Concerning fixed

Corresponding Author: Aslinda 
procedure (PROTAP) controlling of building and guidance of informal sector trader (Street Vendors) in Makassar City area [15].

The basic value of spatial utilization by street vendors listed in [11] States that (1) The regent determines/regulates the courtyard area which can be used by street vendors in groups and individuals as a place of trade/business; (2) prohibiting from trading/striving on the street, sidewalks and other public places, street vendors who have been permitted may not build permanent buildings [13].

Furthermore, the Regulation of the Minister of Home Affairs [14] mentioned that the location of street vendors is the designated location for the street vendors set by the local government, both permanent and temporary.

There is a substantial difference between the basic value of spatial utilization by street vendors based on [11] [13] [14]. The difference between the local regulation, Presidential and ministerial regulation meant based on regulation business place of street vendors that is in article 2 paragraph 2 of Makassar City regulation which expressly states that in the banned trade / strive part of the road, sidewalk and other public places, street vendors who have been permitted may not build permanent buildings. While in the Presidential regulation and ministerial regulation not explained explicitly. The clarity on the location arrangement of street vendors in Makassar city regulation is an adjustment of the entire policy of Makassar City government to support the vision of Makassar City as Makassar City World and support RPJMD as regional development planning of Makassar City.

Differences of basic value of spatial utilization in president and Minister Regulation that are different from those contained in the Makassar City regulation on the location of street vendors of business regulation entitled to change the various regulations or policies of local government of Makassar City on various matters concerning the management of business place of street vendors in spatial utilization by street vendors.

\section{B. Policy Core Beliefs of the Actors in policy of spatial utilization by street vendors}

Policy core belief is the way of actors coordinating actions with their allies in an advocacy coalition to increase their chances of success. The advocacy coalition assumes shared beliefs. The advocacy coalition is a policy participant who [1] has the same basic beliefs of policy and [2] engages in a serious degree of coordination. Individuals form an advocacy coalition based on shared beliefs and their follow-up actions based on their similar beliefs. The basic belief shared by actors in an advocacy coalition is called policy beliefs.

This policy belief contains perceptions and values. Policy belief determine individual choices and actions. In its efforts to achieve policy goals, members of an advocacy coalition act primarily in the same rhythm of coordinating their activities and developing strategies from time to time in order for government institutions to act in accordance with the actor's policy beliefs. Based on the policy belief, it fights for, the advocacy coalition within the policy sub system can generally be divided into dominant and minority coalitions, [8].

The results of this research found that the actors who are incorporated in the policy of spatial utilization by the street vendors in Makassar and have influence in spatial arrangement is a group of government actors of Makassar City. These actors include the Mayor of Makassar; Regional Secretary; Development Assistant, Department of Industry and Trade; City Planning Agency; Department of Cooperation; Department of Market Management; Department of Public Works; Department of Investment and Civil Service Police Unit of Makassar City.

Policy Core Belief actor of SKPD is different according to licenses issued but in the implementation of spatial utilization by street vendors, actors in SKPD have the same belief with the Mayor of Makassar creating Makassar city to be clean and beautiful. This is evident from the program offered by the Mayor of Makassar in relocating street vendors at three location spots. Two of these locations are located in area of Anjungan Pantai Losari, on Penghibur and Metro Tanjung Bunga Street. Another one on Kajalalido Street, Win-win solution offered by Mayor of Makassar in relocating street vendors, around 420 street vendors consisting of 127 hawkers, 128 Pisang epek traders, 165 traders in the lagoon.

To avoid conflicts between government and street vendors who are increasingly growing day by day, the government conducted data collection, by giving registration number to the street vendors of citizen card's holder of Makassar City and have settled in Makassar for 10 years. "In addition, the street vendors to be registered are Street vendors who have registered with "Smart Card. The registered street vendors, who will occupy the integrated relocation of street vendors Makassar.

Furthermore, this research found that in addition to the Government Actors in policy of spatial utilization by street vendors, also found Actors who are incorporated in the street vendors groups namely Association of Street vendors of Makassar Mall (ASPEK - 5), Makassar Legal Aid, Association of Indonesian street Vendors APKLI, Street Vendors' Community of Losari Beach, Association of Street vendors (ASPEK-5), Advocacy and Children's Education Institute (LAPAR), Merchants' Union (PPK-5), Institute Society Activists (AcSi), Municipal Poor Union (SRMK).

From the research findings intended above, actors from organization of street vendors have different belief with the government of Makassar City and street vendors namely policy core belief of the government creating clean and wonderful Makassar City. While policy core belief of street vendors namely earning for their family without paying attention to the beauty of Makassar city.

Belief differences between the government and the street vendors, cause conflict either vertically or horizontally, any conflicts that occur from the spatial utilization by street vendors struggled by the association of institutions, or organizations of street vendors. The organization of these 
street vendors became an aspiration extension in assisting street vendors when the government controls.

\section{Policy Impact of Spatial Utilization by Street Vendors}

The policy impact refers to the ACF model [9] [10] [3], namely the impact on parameters of the targeted problem and its side effects.

Based on the structuring policy of technical street vendors has set the target parameters according to their main tasks and functions and their authority. Example The Department of spatial and building service establishes simplified parameter targets into three parameters, namely: (1) conformity of the utilization permit by street vendors with laws and regulations; (2) conformity of spatial planning time by street vendors with existing permits; and (3) economic growth, local revenues, and the improvement of people's welfare, The first parameter target is the conformity of the permit with the legislation, based on the result of the research, there is no suitability in the spatial utilization by street vendors with legislation as an example in development area I (WP I) and development area III (WP III) along main road of Mesjid Raya street and along Perintis Kemerdekaan street found almost all the main road segment is seen many street vendors who do sales activities in the public area. The sidewalk, by making a permanent building on pedestrian distribution area and city park in Makassar City, whereas in [11] about street vendors about street vendors' training stating that the street vendors are not allowed to do sales activities in areas of distribution of walking, sidewalks and city parks, because the area is a public area that has been regulated utilization based on government regulations. In accordance with the legislation has caused problems that affect the conflict between the Government, street vendors, and the Community, In addition to conflict between levels of government.

The second parameter target of conformity zone or zone designation based on the results of the research found that until now the suitability of spatial utilization based on zones or designation has not been achieved, does not even show indications in a positive result., The third parameter target, the increase of economic growth, the local income, and the increase of the people's welfare, based on the result of the research, found that while the parameter of economic growth, local revenue in Makassar City has shown a positive target achievement. The economy of Makassar City during the period 2007-2012 grew positively measured by GDP growth at current prices. Informant researcher stated that

\section{...Makassar's economic growth rate is the highest ranked in Indonesia with an average of above 9\% over the last five years"(Interview with DS, July 14, 2017)."}

From these statements illustrate that the street vendors occupy spaces that are not designated because the government has not set a place for street vendors in an integrated location in the public arranged and beautiful areas that become characteristic for the whole community and can support the vision of Makassar City as the world city, it is based on based on that in various regions or developed countries, in the arrangement of street vendors of local government and city planners think together places for trading.

\section{CONCLUSION}

Policy core belief of the government creating clean and wonderful Makassar City. While policy core belief of street vendors namely earning for their family without paying attention to the beauty of Makassar city.

\section{REFERENCES}

[1] D.H. Rosenbloom, and R.S Kravchuk.,Public Administration: Understanding Management, Politics, and Law in the Public Sector. Boston: McGraw-Hill, 2005.

[2] Aslinda, Guntur, National Seminar "Building Indonesia through the results of Research With the title Date 26-27 Agustus 2017, Advocacy Coalition Model in The Change of Space Utilization Policy by Street Vendors in Makassar City,2017

[3] C.M Weible, A. Sabatier, Paul, and K. McQueen, in Aslinda, and Akmal Muhammad, Themes and Variations: Taking Stock of the Advocacy Coalition, 2013.

[4] P.A. Sabatier, and Jenkins-Smith, The Advocacy Coalition Framework: An Assessment. In Theories of the Policy Process. edited by Paul A. Sabatier. C. Boulder, 1999.

[5] P.A. Sabatier and D.A.Mazmanian, The Implementation of Public Policy: A Framework of Analysis. Policy Studies Journal, 8 (special issue): 1980.,pp.538-60.

[6] P.A Sabatier,Top-down and Bottom-up Approaches to Implementation Reserach: A Critical Analysis dan Suggested Synthesis. Journal of Public Policy, 1986,pp.6:21-48.

[7] J. W Creswell, Research Design: Qualitative, Quantitative, and Mixed Methods Approaches. London: Sage Publications, Inc, 2003.

[8] P.A. Sabatier and H.Jenkins-Smith, in Aslinda,Model of Advocacy Coalition in Spatial Policy Changes in Makassar City, Doctoral Dissertation at the Department of Public Administration Study, Hasanuddin University, Makassar, 2013.

[9] P.A Sabatie,The Need for Better Theories, in Theories of the Policy Process, edited by P. A. Sabatier. Boulder, CO: Westview Press, 2007, pp 3-20.

[10] P. A. Sabatier, and H.Jenkins-Smith,Policy Change and Learning: An Advocacy Coalition Approach. Boulder, Colo.: Westview Press, 1993.

[11] Local Regulation of Makassar City No.10 Year 1990 on The Development Of Street Vendors in the Area of Makassar City.

[12] Local Regulation of Makassar City Number 6 Year 2006 About Makassar Spatial Plan Area Plan

[13] Presidential Regulation No. 125/2012 on Coordination of Structuring and Empowerment of Street vendors

[14] Regulation of the Minister of Home Affairs Number 41 in 2012 on Guidelines for Structuring and Empowerment of Street vendors

[15] Decision of Mayor of Makassar No. 20 in 2004 concerning fixed procedure (PROTAP). 